\title{
Effect of habitat heterogeneity on bird assemblages in a grassland-forest ecotone in Brazil
}

\author{
André de Mendonça-Lima, Solana Meneghel Boschilia, \\ JoRgE BERNARDO-SILVA ${ }^{*}$ RONEI BALDISSERA ${ }^{\ddagger}$ \\ roneibaldissera@unochapeco.edu.br
}

\begin{abstract}
Resumo
O presente estudo avaliou diferenças na diversidade alfa e beta, e na estrutura de guildas de aves ao longo de uma área de ecótono entre campo e floresta de Araucária no sul do Brasil. Aves foram amostradas por pontos de escuta ( $25 \mathrm{~m}$ de raio) dispostos no campo, na borda e no interior da floresta, agrupados em três blocos. O campo apresentou menor riqueza de espécies e menor abundância. A composição de aves e a estrutura das guildas no campo foram diferentes da borda e do interior da floresta. O campo apresentou mais granívoros, enquanto o interior da floresta apresentou mais onívoros, insetívoros e insetívoros/frugívoros. Apesar disso, houve uma sobreposição na ocorrência de algumas espécies de aves da floresta na borda e no campo, evidenciando que capões e arbustos presentes no campo podem facilitar os movimentos de algumas espécies de aves, o que pode influenciar na dinâmica de expansão da floresta sobre os campos. .
\end{abstract}

Palavras Chave: Expansão Florestal, Diversidade Local, Diversidade Beta.

\section{Bird diversity at grassland-forest ecotone}

\begin{abstract}
The present study evaluates differences in alpha and beta diversity and guild structure of bird assemblages along the ecotone between grassland and Araucaria forest in Southern Brazil. Birds were sampled by point counts (radius of $25 \mathrm{~m}$ ) disposed in the grassland, in the grasslandforest edge, and in the forest interior, grouped in three blocks. Grassland presented low bird richness and abundance, and the bird composition and guild structure in grasslands were different from the edge and the forest interior. Grassland showed more granivores, while forest interior presented more omnivores, insectivores and insectivores/ frugivores. Notwithstanding, there was an overlap on the occurrence of some forest bird species in the edge and grassland, evidencing that the grassland plant structure composed of small forest patches and shrubs could facilitate bird movements, which, in turn, could influence forest expansion dynamics over the grassland.
\end{abstract}

key words: Forest Expansion, Local Diversity, Beta Diversity.

*Programa de Pós Graduação em Ecologia - Universidade Federal do Rio Grande do Sul

${ }^{\dagger}$ Instituto Geociências - Universidade Federal do Pará

‡Programa de Pós Graduação em Ciências Ambientais - Universidade Comunitária da Região de Chapecó 


\section{INTRODUCTION}

$\mathrm{R}$ Egional diversity may be decomposed in alpha and beta diversity (WHITTAKER, 1960). The first may be the composition of a local community, i.e. the number of different taxa within one specific object (sampling unit), and may also be the mean diversity of a set of local communities; and beta diversity accounts for the differences of local community compositions within a landscape (WHITTAKER, 1960; LEGENDRE et al., 2005). At the local scale, animal diversity may be benefited by the presence of structurally complex habitats, which offers more opportunities to niche occupation (BAZZAZ, 1975; TEWS et al., 2004). The local physical structure can be determined by plant community, which in turn influences the animals' species interaction and distribution (MACARTHUR \& MACARTHUR, 1961; LAWTON, 1983). On the other hand, at the regional scale typically there is a set of different local environments producing differential distribution of local compositions among local sites, which can arise by processes linked to species' adaptations to certain characteristics of the habitat (e.g. climate or substrate), to the dispersal limitation and to historical effects (LEGENDRE et al., 2005; VEECH \& CRIST, 2007).

Along ecotones, the composition of local communities within a habitat is supposed to vary as one moves along the gradient towards the contact area between ecosystems - the edge. At this area there may be a mixture of biotas, and therefore a decrease in beta diversity compared to contrasting sites within each particular ecosystem. In this scenario, local diversity should be higher at the more heterogeneous ecosystem. Considering the bird fauna, the increase of local environmental complexity and heterogeneity within forest sites promote the increase of trophic levels and species richness due to higher possibilities of spatial and food exploitation (GIMENES \& ANJOS, 2003).

The North-Eastern region of Rio Grande do Sul state in Southern Brazil is characterized by the presence of relictual grasslands interspersed with Araucaria forest. At the biogeographic level, climatic and edaphic features contribute to set adequate conditions for the forest community expansion in the region (RAMBO, 1956), a process that has been occurring for the last 4,000 years (IRIARTE \& BEHLING, 2007; SILVA \& ANAND, 2011). Locally, the natural dynamic of forest expansion is due mainly by the presence of nurse plants that potentially facilitate the recruitment of dispersers and increase the seed rain (GUEVARA et al., 1992; PADILLA \& PUGNAIRE, 2006; CARLUCI et al., 2011). The process changes the habitat structure in the grassland areas nearby forest edges, which could affect the distribution of bird local and beta diversity, and guild structure at the interface between the forest and the grassland. Therefore, the present study aimed to assess the bird richness, abundance, composition and guild structure in forest interior, edge, and grassland areas in Southern Brazil. Based on the local spatial heterogeneity approach (MACARTHUR et al., 1962; AMARASEKARE \& NISBET, 2001), we expected to find more species richness and abundance inside forest areas followed by edge areas. Additionally, we also predicted different species composition and guild structure in the three areas studied, with the edge presenting a mixture of grassland and forest bird compositions (EWERS \& DIDHAM, 2006).

\section{Methods}

\section{Study area and bird sampling}

The study was conducted at three interface areas between Araucaria forest and grassland in Pró-Mata Research and Nature Conservation Centre (CPCN Pró-Mata; $\left.29^{\circ} 28^{\prime} \mathrm{S}, 5^{\circ} 13^{\prime} \mathrm{W}\right)$, Rio Grande do Sul state, Southern Brazil (900 m.a.s.l.). Climate is temperate, mesothermic and super humid. The annual average temperature is $14.5^{\circ} \mathrm{C}$, and the mean annual rainfall is ca. 2,250 $\mathrm{mm}$ (NIMER, 1989). The main vegetation types are grasslands, and two Atlantic forest formations: Araucaria forest (Mixed Ombrophilous Forest) and Dense Ombrophilous 
Forest (BERTOLETTI \& TEIXEIRA, 1995). Since 1993, land owners interrupted the fire and the cattle production in the region, which allowed the growing of bushy vegetation within the grassland. The study site included a grassland patch (ca. 78 ha) presenting different forest patches, surrounded by a continuous forest (DUARTE et al., 2006) (Figure 1). The site sample consisted of three blocks, each one with nine sampling units (distant $150 \mathrm{~m}$ from each other) disposed at each one of three distances from the forest: three sampling units $150 \mathrm{~m}$ inside forest, three at the edge of forest, and three $150 \mathrm{~m}$ inside grassland. The three blocks were located at least $150 \mathrm{~m}$ from each other. During 10 minutes in each point the first author counted and identified all birds heard or seen around a circular buffer of $25 \mathrm{~m}$ (BIBBY et al., 2000). The sampling was made in January 13, 14, and 15, 2009 between 7:00 and 10:30 am. Bird species were classified in food guilds such as frugivores, insectivores, frugivores/insectivores, granivores, carnivores, omnivores and nectarivores (STOTZ et al., 1996; SICK, 1997).

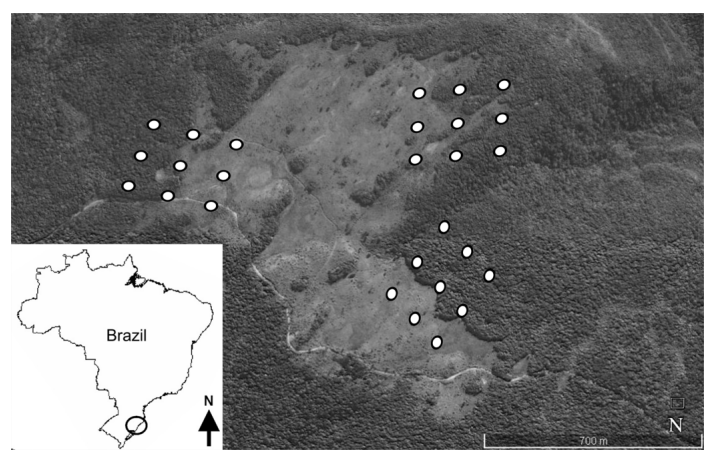

Figure 1: Grassland patch surrounded by Araucaria forest in Southern Brazil with schematic representation of the three areas studied (not in scale).

Clearly, our study was a snapshot of the bird community in the region. In fact, the study was thought in short terms because it was the only time at disposal for the researcher team to perform the collections. But because our main objective was to compare the distribution patterns of local bird communities among three contiguous habitats, we believe the sampling achieved its goals and the observed results corroborate this impression.

\section{Statistical analyses}

We calculated the Durbin-Watson D statistic in order to verify the statistical independence of sampling units based on first order autocorrelation (SAS Institute Inc. 2008). Typically, Durbin-Watson D statistic must not fall far from "2" and the calculated first order autocorrelation must be between $\pm 2 / \sqrt{ } \mathrm{n}$ to decide in favor of independence (SAS Institute Inc. 2008). Considering the 27 sampling units, the first order autocorrelation must fall between \pm $2 / \sqrt{ } 27=0.385$.

Chao 1 estimator was used to estimate the absolute number of species in the whole bird community based on the observed richness (MAGURRAN, 2004). Randomization based ANOVAs (PILLAR, 2006) were used to check for differences in bird richness and abundance among habitats based on Euclidean distances between sampling units. Individual-based rarefaction was calculated prior to the analysis in each sampling unit and the resulting estimates were interpolated to the smaller abundance value in order to standardise sampling effort (GOTELLI \& COLWELL, 2001). Two randomization based MANOVAs (PILLAR, 2006) were done to assess differences in the bird species composition and the guild structure based on two dissimilarity matrices (chord distance): presence-absence matrix of bird species and the number of occurring species in each guild. Two bootstrapped ordination analyses (PCoA) were performed in order to visualize the distribution patterns of sampling units. Bootstrapped ordination evaluates the significance of ordination axes $(\alpha<0.1)$ and also can be used to evaluate sampling sufficiency if bootstrap samples with increasing sizes are selected (PILLAR, 1998, 2006). Analyses were done using software Multiv (PILLAR, 2006; free available at http: //ecoqua.ecologia.ufrgs.br/main.html). 
Table 1: MANOVA results comparing bird composition in grassland, edge, and forest interior. Analysis were done based on a chord distance dissimilarity matrix based on bird presence in 27 sampling units separated in three blocks along an interface area between grassland and Araucaria forest in Southern Brazil.

\begin{tabular}{lcc}
\hline Source of variation & Sum of squares & $\mathbf{b}$ \\
\hline Between distances Contrasts & 4.028 & 0.001 \\
Grassland $x$ edge & 2.186 & 0.002 \\
Grassland $x$ forest & 2.981 & 0.001 \\
Edge $x$ forest & 0.875 & 0.098 \\
TOTAL & 20.932 & \\
\hline
\end{tabular}

\section{Results}

Autocorrelation analyses showed that the sampling units were independent based on Durbin-Watson D statistics $\left(\mathrm{D}_{\text {richness }}=2.452\right.$, first order autocorrelation $=-0.235 ; \mathrm{D}_{\text {abundance }}=$ 1.637 , first order autocorrelation $=0.179$ ). A total of 240 individuals divided in 55 bird species was detected. Based on Chao 1 richness estimator they represent about $73 \%$ of the total regional diversity for the study area considering the same sampling effort. The grassland showed lower mean bird rarefied richness (3.30 species \pm 0.08 standard error), while the richness in the forest edge $(3.72 \pm 0,07)$ and the forest interior $(3.69 \pm 0,06)$ were similar $(\mathrm{SS}=$ 0.9685; $\mathrm{P}=0.001$ ) (Figure 2). The same pattern held for bird abundances, the abundance in the grassland was lower $(5.89 \pm 0.59)$ than the edge $(10 \pm 1.67)$ and forest interior (10.78 \pm 0.68) ( $\mathrm{SS}=124.22 ; \mathrm{P}=0.001$ ) (Figure 2 ).

Regarding the compositional analysis, it was found that the first axis of ordination was significant $(P=0.05)$, therefore we assumed both sampling sufficiency and consistent pattern of bird compositional variation for this study. Bird species composition in the grassland was significantly different from the two other habitats (Table 1; Appendix A). Only two species were found exclusively in the grassland, seven species were found only in the forest edge and 18 occurred only in the forest interior. Elaenia mesoleuca (Deppe, 1830) was the most abundant species found at the forest edge and interior. Five species occurred in all habi- tats: Haplospiza unicolor (Cabanis, 1851), Leucochloris albicollis (Vieillot, 1818), Phylloscartes ventralis (Temminck, 1824), Stephanophorus diadematus (Temminck, 1823) and Thamnophilus caerulescens Vieillot, 1816. The ordination of sampling units based on species composition showed slightly overlap of grassland and forest edge (Figure 3). Zonotrichia capensis (Müller, 1776) was associated with the grassland. E. mesoleuca, S. diadematus and Poospiza cabanisi Bonaparte, 1850 were associated with the forest interior bird fauna. Myiophobus fasciatus (Statius Muller, 1776), Synallaxis spixi Sclater, 1856, and Chlorostilbon aureoventris (Shaw, 1812) were associated with the forest edge area (see title of Figure 3 for coefficients of correlation between species and the first axis of ordination).

The bird guild structure in the grassland was significantly different from the other habitats (Table 2; Figure 3). The grassland showed mostly the presence of granivores species although some sampling units showed nectarivores, carnivores and omnivores species. Insectivores and insectivores/frugivores occurred primarily in forest edge and forest interior, but at least two grassland sampling units also showed the presence of frugivores.

\section{DISCUSSION}

We were able to show a consistent pattern of bird fauna diversity along the ecotone gradient in spite of the point spatial and temporal scale of the study. Bird richness, abun- 
Table 2: MANOVA results comparing bird guild structure in grassland, edge, and forest interior. Analysis were done based on a chord distance dissimilarity matrix based on number of bird species occurrences on seven guilds in 27 sampling units separated in three blocks along an interface area between grassland and Araucaria forest in Southern Brazil.

\begin{tabular}{lcc}
\hline Source of variation & Sum of squares & $\mathbf{P}$ \\
\hline Between distances Contrasts & 2.445 & 0.001 \\
Grassland $x$ edge & 1.440 & 0.01 \\
Grassland $x$ forest & 2.045 & 0.001 \\
Edge $x$ forest & 0.182 & 0.539 \\
TOTAL & 8.631 & \\
\hline
\end{tabular}

dance, composition, and guild structure along grassland-Araucaria forest gradient indicated differences underlying the presence of specific bird assemblages, a pattern also found by Moradi et al. (2009) for an insectivore guild in forest remnants of Malaysia. MacArthur et al. (1962) stated that a habitat supports more species due to its large internal variation in vegetation layer (leaf density plotted against height). In fact, Cody (2001) emphasised that bird richness could be altered in a region according to plant structure modification, and the bird density could be predicted by the measurement of plant density. Moreover, Gottschalk et al. (2007) found differences in breeding bird occurrence associated to the structure of sampled grasslands.

In the present study, a gradient of plant structural alterations can be found at the interface between grassland and forest. Commonly, the lowest plant layer (i.e. up to $\sim 1$ $\mathrm{m})$ occurs in all the three habitats. However, there is a reduction in understory plant coverage coupled with an increase in the overstory as one walks from the edge to the forest interior (FONTOURA et al., 2006) and this feature could affect bird diversity (BAKER et al., 2002; KISSLING et al., 2008). In that sense, for instance the species E. mesoleuca and S. diadematus occurred more in the overstory layer of forest. This fact reaffirms the spatial selective property of the species, which use mostly the middle and the upper layer of forests (BELTON, 1985).

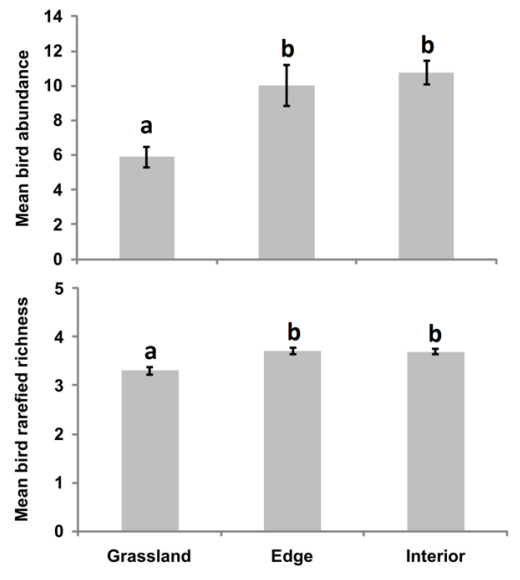

Figure 2: Mean \pm standard errors of bird abundance (upper) and bird rarefied richness (lower) found in grassland, edge, and forest areas in CPCN-Pró-Mata during January 2009.

We were able to find species utilising concomitantly the grassland and the edge. The within beta diversity is higher at these habitats (sites are more distant in the ordination space), which suggests that the grassland areas near the edge presenting shrub layer can provide more spatial heterogeneity that can be used by a more diversified assemblage of birds, including forest generalist species (LLOYD et al., 2011). In that sense, small forest patches or even isolated individuals of the commonly bush Baccharis uncinella (Asteraceae) could be a food source or shelter for a wider array of species (ANJOS \& BOÇON, 1999), like the appearance of the species $S$. diadematus and $P$. 
ventralis in the grassland. This fact is relevant to the process of forest expansion upon the grassland mainly when we consider frugivors species, which are the main seed and fruit disperser agents (SNOW, 1981; OLIVEIRA \& PILLAR, 2004; DUARTE et al., 2006).

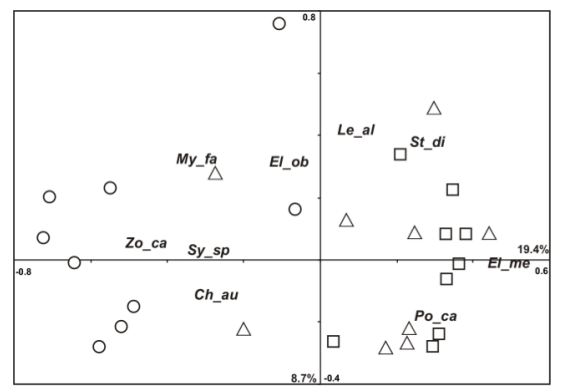

Figure 3: Scores of the first and the second ordination axis (PCOA) of 27 sampling units at the interface between grassland and Araucaria forest in Southern Brazil. Original matrix was 55 bird species presence-absence. Circles $=$ grassland; triangles = edge; squares $=$ forest interior . Species with correlation coefficients with axis 1 greater than 0.5: Zo ca = Zonotrichia capensis; My fa = Myiophobus fasciatus; Sy $\mathrm{sp}=$ Synallaxis spixi; $\mathrm{Ch}$ au $=$ Chlorostilbon aureoventris; $\mathrm{Po} \mathrm{ca}=$ Poopiza cabanisi; $\mathrm{El}$ me = Eleania mesoleuca. Species with correlation coefficients with axis 2 greater than 0.5: El ob = Elaenia obscura; Le al = Leucochloris albicollis; St di = Stephanophorus diadematus.

The responses of bird trophic guilds to the habitat gradient strengthen the above statement concerning species composition. In this way, the number of guilds increases as one moves from grassland to the forest interior, due to increasing food and spatial resource availability (KISSLING et al., 2007, 2008). Thus, granivore species occurred mainly in the grassland, while insectivore and insectivore/frugivore species occurred predominantly in the forest interior. The data underpin other studies that found different bird faunas in different plant types, different abundances in various trophic groups between forest edge and interior, and an increase in the amount of insectivore and frugivore birds occurring in less impacted forests along an agricultural gradient (CASENAVE et al., 1998; WEN et al., 2002; MARSDEN \& SYMES, 2008).

The present study emphasises the importance of keystone habitat structures (TEWS et al., 2004) that affect the bird richness, abundance, composition and guild structure at the interface between grassland and Araucaria forest. The role of plant structures for bird community in the region is crucial because there is a natural dynamic of forest expansion upon the grasslands. The alterations resulting from this expansion like the appearance of forest patches and bushes in the grasslands affect the resource availability to the forest birds, which could facilitate the incursions of seed and fruit dispersers inside the grasslands. Moreover, grassland and edge habitats clearly increase the beta diversity of bird assemblages suggesting that these habitats play an important role in the maintenance of regional bird diversity.

\section{REFERENCES}

AMARASEKARE, P.; NISBET, R.M.Spatial heterogeneity, source-sink dynamics, and the local coexistence of competing species. The American Naturalist, Chicago, v.158, p. 572584, 2001.

ANJOS, L., BOÇON, R. Bird communities in natural forest patches in southern Brazil. Wilson Bulletin, v.111, p. 397-414, 1999.

BAKER, J., FRENCH, K., WHELAN, R. J.The edge effect and ecotonal species: bird communities across a natural edge in southeastern Australia. Ecology, v.83, p. 3048-3059, 2002.

BAZZAZ, F. A. Plant species diversity in oldfield successional ecosystems in southern Illinois. Ecology, v.56, p. 485-488, 1975.

BELTON, W. Birds of Rio Grande do Sul, Brazil, Part 2. Formicariidae through Corvidae. Bulletin of the American Museum of Natural History, v.180, p. 1-242, 1985. 
BERTOLETTI, J. J., TEIXEIRA, M. B. Centro de Pesquisas e Conservação da Natureza Pró Mata. Termo de Referência. Divulgações do Museu de Ciências e Tecnologia - UBEA/PUCRS 2., Porto Alegre, PUCRS, p. 1-47, 1995.

BIBBY, C. J., HILL, D. A., BURGESS, N. D., MUSTOE, S. Bird Census Techniques. , London, Academic Press Limited, p. 320, 2000.

CARLUCI, M. B., TEIXEIRA, F. Z., BRUM, F. T., DUARTE, L. Edge expansion of Araucaria forest over southern Brazilian grasslands relies on nurse plant effect. Community Ecology, v. 12, p. 196-201, 2011.

CASENAVE, J. L., PELOTTO, J. P., CAZIANI, S. M., MERMOZ, M., PROTOMASTRO, J. Responses of avian assemblages to a natural edge of a Chaco Semiarid Forest in Argentina. The Auk, v. 115, p. 425-435, 1998.

CODY, M. Bird diversity components in Australian Eucalyptus and North-Temperate Quercus Woodlands. The Auk, v. 118, p. 443456, 2001.

DUARTE, L. S., MACHADO, R. E., HARTZ, S. M., PILLAR, V. D. What saplings can tell us about forest expansion over natural grasslands. Journal of Vegetation Science, v. 17, p. 799-808, 2006.

EWERS, R. M, DIDHAM, R. K. Confounding factors in the detection of species responses to habitat fragmentation. Biological Reviews, v. 81, p. 117-142, 2006.

FONTOURA, S.B., GANADE, G., LAROCCA, J. Changes in plant community diversity and composition across an edge between Araucaria forest and pasture in South Brazil. Brazilian Journal of Botany, v. 29, p. 79-91, 2006.

GIMENES, M. R., ANJOS, L. Efeitos da fragmentação florestal sobre as comunidades de aves. Acta Scientiarum Biological Sciences, v. 25, p. 391-402, 2003.

GOTELLI, N. J., COLWELL, R. K.Quantifying biodiversity: procedures and pitfalls in the measurement and comparison of species richness. Ecology Letters, v. 4, p. 379-391, 2001.

GOTTSCHALK, T. K., EKSCHMITT, K., BAIRLEIN, F. Relationships between vegetation and bird community in grasslands of the Serengueti. African Journal of Ecology, v. 45, p. 557-565, 2007.

GUEVARA, S., MEAVE, J., MORENOCASSOLA, P., LABORDE, J. Floristic composition and structure of vegetation under isolated trees in neotropical pastures. Journal of Vegetation Science, v. 3, p. 655-664, 1992.

IRIARTE, J., BEHLING, $\mathrm{H}$. The expansion of Araucaria forest in the southern Brazilian highlands during the last 4000 years and its implication for the development of the Taquara/Itararé formation. Environmental Archaeology, v. 12, p. 115-127, 2007.

KISSLING, W. D., RAHBEK, C., BÖHNINGGAESE, K. Food plant diversity as broadscale determinant of avian frugivore richness. Proceedings of the Royal Society B: Biological Sciences, v. 274, p. 799-808, 2007.

KISSLING, W. D., FIELD, R., BÖHNINGGAESE, K. Spatial patterns of woody plant and bird diversity: functional relationships or environmental effects? Global Ecology and Biogeography, v. 17, p. 1-13, 2008.

LAWTON, J. H. Plant architecture and the diversity of phytophagous insects. Annual Review of Entomology , v. 28, p. 23-39, 1983.

LEGENDRE, P., BORCARD, D., PERES-NETO, P. R. Analyzing beta diversity: partitioning the spatial variation of community composition data. Ecological Monographs, v. 75, p. 435-450, 2005.

LLOYD, H., RÍOS, S. S., MARSDEN, S. J., VALDÉS-VELÁSQUEZ, A. Bird community composition across an Andean treeline ecotone. Austral Ecology, v. 37, n. 4, p. $470-478,2011$. 
MACARTHUR, R. H., MACARTHUR, J. W. On bird species diversity. Ecology, v. 42, p. 594-598, 1961.

MACARTHUR, R. H., MACARTHUR, J. W., PREER, J. On bird species diversity. II. Prediction of bird census from habitat measurements. American Naturalist , v. 46, p. 167174, 1962.

MARSDEN, S. J., SYMES, C. T. Bird richness and composition along an agricultural gradient in New Guinea: the influence of land use, habitat heterogeneity and proximity to intact forest. Austral Ecology, v. 33, p. 784-793, 2008.

MORADI, H. V., ZAKARIA, M., MOHD, A. B., YUSOF, E. Insectivorous birds and environmental factors across an edge-interior in tropical rainforest of Malaysia. International Journal of Zoological Research, v. 5, p. 27-41, 2009.

NIMER, E. Climatologia do Brasil., Rio de Janeiro, IBGE, 421 p., 1989.

OLIVEIRA, J. M., PILLAR, V. D. Vegetation dynamics on mosaics of Campos and Araucaria forest between 1974 e 1999 in Southern Brazil. Community Ecology , v. 5, p. 197202, 2004.

PADILLA, F. M., PUGNAIRE, F. I. The role of nurse plants in the restoration of degraded environments. Frontiers in Ecology and the Environment, v. 4, n. 4, p. 196-202, 2006.

PILLAR, V. D. MULTIV: Multivariate Exploratory Analysis, Randomization testing and bootstrap resampling; User's guide $v$. 2.4. , Porto Alegre, Departamento de Ecologia, UFRGS, 42 p., 2006.

PILLAR, V. D. Sampling sufficiency in ecological surveys. Abstracta Botanica , v. 22, p. 37-48, 1998.

RAMBO, B. A fisionomia do Rio Grande do Sul. , Porto Alegre, Livraria Selbach, 456 p.,1956.
SAS INSTITUTE INC. SAS/STAT 9.1 User's Guide: The REG Procedure (Book Excerpt). , Cary, NC: SAS Institute Inc., 2008.

SICK, H. Ornitologia brasileira. , Rio de Janeiro, Editora Nova Fronteira, 912 p. 1997.

SILVA, L. C. R., ANAND, M. Mechanisms of Araucaria (Atlantic) forest expansion into southern Brazilian grasslands. Ecosystems, v. 14, p. 1354-1371, 2011.

SNOW, D. W. Tropical frugivorous birds and their food plants: a world survey. Biotropica, v. 13 , p. $1-14,1981$.

STOTZ, D. F., FITZPATRICK, J. W., PARKER, T. A., MOSKOVITS, D. K. Neotropical birds: ecology and conservation., Chicago, University of Chicago Press, 478 p., 1996.

TEWS, J., BROSE, U., GRIMM, V., TIELBORGER, K., WICHMANN, M. C., SCHWAGER, M., JELTSCH, F. Animal species diversity driven by habitat heterogeneity/diversity: the importance of keystone structures. Journal of Biogeography, v. 31, p. 79-92, 2004.

VEECH, J. A., CRIST, T. O. Habitat and climate heterogeneity maintain beta-diversity of birds among landscapes within ecoregions. Global Ecology and Biogeography, v. 16, p. 650-656, 2007.

WEN, W, MARUYAMA, N., BO-WEN, L., MORIMOTO, H., ZHONG-XIN, G. Relationships between bird communities and vegetation structure in Honghua'erji, northern inner Mongolia. Journal of Forest Research, v. 13, p. 294-298, 2002.

WHITTAKER, R. H. Vegetation of the Siskiyou Mountains, Oregon and California.Ecological Monographs , v. 30, p. 279-338, 1960.

WHITTAKER, R. H. Vegetation of the Siskiyou Mountains, Oregon and California.Ecological Monographs , v. 30, p. 279-338, 1960. 